\title{
Boosting Minority Teacher Recruitment and Retention for a Diverse Future STEM Workforce
}

\section{$\underline{\text { Patricia N. Razafindrambinina }}^{1}$, Aditi Dubey $^{2}$, Paul B. Ellis ${ }^{3}$, $\underline{\text { Rachel Lamb }}{ }^{4}, \underline{\text { Shantam Ravan }}{ }^{5}$}

1University of Maryland, Department of Chemistry and Biochemistry, College Park, MD 20740

2University of Maryland, Department of Entomology, College Park, MD 20740

3University of Maryland, School of Public Policy, College Park, MD 20740

${ }^{4}$ University of Maryland, Department of Geographical Sciences, College Park, MD 20740

5University of Maryland, Department of Physics, College Park, MD 20740

https://doi.org/10.38126/ISPG180414

Corresponding author: prazafin@umd.edu

Keywords: education; STEM; minorities; teacher; recruitment; retention; diversity

Executive Summary: The United States STEM workforce has yet to reflect the demographics of the larger population. This discrepancy begins at the base of the STEM pipeline with a significant lack of minority STEM K-12 teachers to serve as mentors and role models to minority students. Research has shown that minority students' exposure to same-race teachers increased academic output and education attainment up to 32\%. Unfortunately, minority teachers face a revolving-door effect: the cycle of increased recruitment countered by a high turnover amongst minority teachers compared to their white counterparts. Minority teachers who leave the profession consistently cite negative teaching environments, discrimination, and lack of support as the main drivers of their decision to quit teaching. The Maryland state legislature recently passed the Blueprint for Maryland's Future Act, which attempts to address teacher recruitment and retention more comprehensively. Here, we go beyond the Blueprint's baseline tools to recommend targeted strategies to recruit and retain minority STEM K-12 teachers in Maryland. Through the creation of a robust peer mentorship pipeline between new and experienced teachers, prioritization of school staff diversity and inclusion training, and the promotion of teacher autonomy, we will increase minority student education attainment and encourage the growth of a diverse STEM workforce in Maryland.

\section{Statement of issue}

Despite increased recruitment of skilled STEM workers throughout the economy, the demographics of the STEM workforce still fails to reflect the demographics of the population it serves. The gender, racial, and ethnic makeup of the STEM talent pool in the US has seen little change since the 1980s, with white or Asian males comprising 84\% of working professionals in STEM (NSF National Center for Science and Engineering Statistics 2021). This lack of diversity can be linked to the lack of minority representation in K-12 STEM teachers, which plays a major role in the educational attainment of samerace students.

There is increasing evidence that mentorship by same-race teachers has positive impacts on students, such as increased academic achievement, better attendance, and up to a $29 \%$ reduction in dropout and suspension rates. Additionally, research shows that teacher diversity can contribute to closing achievement gaps by up to $32 \%$ for minority students (Lindsay and Hart 2017). Minority teachers are also more likely than their white counterparts to 
refer students to gifted programs and support minority students by fostering an inclusive classroom climate (Papageorge, Gershenson, and Kang 2018).

Unfortunately, the entire K-12 teaching workforce in Maryland has yet to reflect the demographics of their student bodies: $62 \%$ of students are non-white compared to just $26 \%$ of teachers. One in five schools have no Black teachers, and almost half of all schools have no Latinx teachers (Maryland State Education Association 2018). Considering the benefits that all students gain from having at least one minority teacher, such as exposure to positive role models that counteract negative stereotypes, Maryland has much to gain by diversifying its education staff.

High attrition rates and low retention of minority teachers must be addressed: elevated turnover rates of minority teachers in high-minority communities create increased demand for new teachers to fill positions (R. Ingersoll and May 2011). The extreme demand for teachers leads to a disproportionate number of inexperienced teachers $(<3$ years of teaching) in underrepresented minority communities (Shwe 2020). Minority teachers who departed the profession cite challenging teaching conditions, lack of professional and administrative support, and limited opportunities for advancement as their primary factors for leaving (Polidore, Edmonson, and Slate 2010).

Promoting retention, support, and well-being of minority teachers is a labor and education challenge that needs further policy guidance. We propose to tackle the issue of minority teacher attrition through a series of policy recommendations to the Maryland State Department of Education which will benefit Maryland students and future STEM workforce for years to come.

\section{Current policy landscape}

In Spring 2021, the Maryland General Assembly passed the "Blueprint for Maryland's Future", an educational overhaul aimed at addressing systemic concerns in K-12 education and a slip in the state's public school national rankings (Tooten 2019). The Blueprint increases grant funding for teacher training programs, raises teacher salaries, and provides more professional development opportunities (Ferguson et al. 2020). These mechanisms are intended to raise the prestige of the teaching profession and make it a more attractive career path for STEM college graduates. The Blueprint makes major strides in Maryland; however, while this statute has helped to redefine the baseline for Maryland education, the Blueprint does not specify how individual districts should target K-12 teacher diversification, recruitment, and retention. Higher salaries suggested by the Blueprint may help attract highly qualified STEM K-12 teachers from underrepresented minority groups, but they must be accompanied by targeted improvements to the teaching environment, as well as teacher peer mentorship programs and administrative support to address the shortcomings of the current educational system.

\section{Policy recommendations}

Here, we outline several policy recommendations to provide targeted support to minority teachers. Rather than calling for increased funding (which may be impeded by the fiscal impacts of COVID-19), our recommendations are strategic changes executable by the Maryland State Department of Education that will further enhance minority teacher recruitment and retention. Our recommendations address the issue of minority teacher retention through incremental changes that will drive a systemic culture shift towards diversity, equity, and inclusivity for teachers, students, and school districts alike.

\section{i. Mentorship pipeline for recruitment and retention} Allocate a portion of funding from the Blueprint to increase the prestige of a teaching career through career exploration and mentorship programs directed towards university graduates to achieve dual goals:

\section{Recruitment}

Expand interest of STEM college graduates from instate universities in $\mathrm{K}-12$ teaching as a rewarding and profitable career. The Maryland State Department of Education should create an immersive teaching career workshop at each $\mathrm{K}-12$ school district, targeted towards minority STEM university graduates and graduate students. The series of workshops will form communities of practice and increase cohesion and networking among STEM graduates with an interest in $\mathrm{K}-12$ 
teaching while providing a more accessible and immersive alternative to career fairs (Lopez and Duran 2021). We recommend allocating funds to offer pay and certification for attending such summer programs to further expand the pool of STEM graduate students and professionals attending.

\section{Retention}

Acquaint early career minority teachers with minority peer mentors in similar fields across jurisdictions. The Maryland State Department of Education should create a cross-jurisdictional program to pair minority teachers with a seasoned mentor to help form connections between groups of teaching professionals. Through allocating funds to hold compensated, regular meetings year-round, teachers who may feel culturally isolated would have consistent and personalized support from more experienced minority teachers who have tackled causes of attrition like student behavior, high workload, lack of support, and systemic biases (Barmby 2006).

\section{ii. Reduce discrimination and bias faced by minority teachers in public schools}

Retention of minority teachers in the public school system is hindered by systemic biases and discrimination. Research has shown that Black and Latinx teachers are often perceived by their peers as underqualified, inferior, and are criticized for incorporating culturally relevant learning materials such as languages, traditions, and history of minorities in their respective locations (CarverThomas 2018). Such preconceived notions lead to fewer leadership positions and career advancing roles being assigned to minority teachers, as well as teacher attrition (Bailes and Guthery 2020).

We call on the Maryland State Department of Education to require each public school to host yearly minority-teacher-led professional development seminars that address discrimination and bias against minorities in the public school system, as well as provide monetary incentives to teachers who lead these sessions.

This approach has been strongly endorsed by school administrators (Harvard Law Review 1991) and supported by the Brookings Institution who suggest that training and awareness are essential in creating an inclusive environment (Pope, Price, and Wolfers
2013). A safe and inclusive space will encourage teachers and administrators to address and discuss challenges faced by minorities in their school system, advocate for future minority teachers, and reduce the incidence of such bias in the future.

This recommended action can have a cascading effect: alleviating the biases faced by minority teachers and boosting recruitment of new teachers by encouraging current minority teachers to act as ambassadors (Harvard Law Review 1991). The primary drawback to this strategy is the cost of adding extra responsibilities to an already underpaid, overworked teaching staff. This could be circumvented by introducing monetary incentives to the teachers who run the professional development seminars through direct grants or payments by the state allocated from the Blueprint.

\section{iii. Increase minority teacher retention through} greater autonomy

The lack of teacher retention has been related to job stress, lowered empowerment, and lack of support (Pearson and Moomaw 2005). Unfortunately, teacher autonomy has declined over time, with the percentage of teachers reporting low autonomy increasing from $18 \%$ in $2003-04$ to $26 \%$ in $2011-12$ (Walker 2016).

Limited autonomy is a particular issue for minority teachers, with $33 \%$ of Black and $31 \%$ of Hispanic teachers reporting low autonomy compared to $26 \%$ of white teachers (Walker 2016). Data from the National Center for Education Statistics' School and Staffing Survey from 1987 to 2012 found that individual instructional autonomy within classrooms was the strongest predictor of minority teacher turnover. If statewide attrition rates were similar to those in high autonomy schools, minority teachers would have represented $23 \%$ of the teaching force in 2012 rather than 17.2\% (R. Ingersoll, May, and Collins 2019). Instructional autonomy and teacher leadership has also been linked to higher student achievement, indicating that greater minority teacher autonomy may directly contribute to the larger goal of improving educational outcomes for minority students.

Maryland ranked $48^{\text {th }}$ in teacher-reported autonomy by state in 2012 (Sutcher, Darling-Hammond, and Carver-Thomas 2016). More data must be collected 
through smaller-scale surveys to identify which aspects of decision-making teachers seek a greater role in. For example, teachers often have a role in choosing teaching techniques and grading, but not in determining school-wide policies as shown by their obligation to teach a curriculum focused on standardized exams instead of individualized lifelong learning (R. M. Ingersoll, Sirinides, and Dougherty 2018). The results of these surveys could help shape school and district-level policies to increase teacher autonomy and leadership. The Blueprint for Maryland's Future allocates funds for school leadership training programs (Ferguson et al. 2020); this could include training administrators in how to best support and empower teachers through greater autonomy and participation in decisionmaking.

\section{Conclusion}

Lack of diversity in the STEM workforce can be remedied in part by addressing the first step in the pipeline: the presence of minority $\mathrm{K}-12$ teachers in the classroom. A diverse teaching workforce enhances student experience, challenges stereotypes, and for minority students, a same-race teacher may be the difference between completing their education and dropping out.

Each of our recommendations target one aspect of the minority teacher experience: recruitment,

References

Bailes, Lauren P, and Sarah Guthery. 2020. "Held Down and Held Back: Systematically Delayed Principal Promotions by Race and Gender." AERA Open 6 (2): 2332858420929298. https://doi.org/10.1177/2332858420929298.

Barmby, Patrick. 2006. "Improving Teacher Recruitment and Retention: The Importance of Workload and Pupil Behaviour." Educational Research 48 (3): 247-65.

https://doi.org/10.1080/00131880600732314

Carver-Thomas, Desiree. 2018. "Diversifying the Teaching Profession: How to Recruit and Retain Teachers of Color." Washington, DC. https://learningpolicyinstitute.org/sites/defau It/files/product-

files/Diversifying Teaching Profession REPOR T 0.pdf.

Ferguson, William, Paul Pinsky, Nancy King, Thomas Miller, and Ronald Young. 2020. "SB 1000: Blueprint for Maryland's Future." Maryland Senate. mentorship, and retention. We strongly suggest that the Maryland State Department of Education consider all three of our recommendations and implement them as complementary strategies. The strength of our recommendations is that they do not require additional capital but are instead targeted strategies that utilize funds from the Blueprint for Maryland's Future to actualize its broader goals. Incentivized, immersive career exploratory programs increase interest of minority graduates in $\mathrm{K}-12$ teaching as a fulfilling lifelong career, strengthening minority teacher recruitment. The increased recruitment will be supported by retention efforts through mentorship programs between early career minority teachers and senior teachers who have experienced similar obstacles and biases in the workplace. District-tailored, minority-led diversity and inclusion seminars will provide a safe and inclusive platform for teachers and staff to discuss solutions to bias incidents and systemic discrimination in the school district, which is the primary reason for minority teacher attrition. Lastly, allowing greater teacher autonomy in the classroom, as well as the inclusion of teachers in school-wide decision-making, will increase teacher empowerment and satisfaction, further enhancing minority teacher retention. A strong sense of community and inclusivity is key to elevating the teaching profession and nurturing the future minority STEM workforce of Maryland.

Harvard Law Review. 1991. "Race-Based Faculty Hiring and Layoff Remedies in School Desegregation Cases." Harvard Law Review 104 (8): 1917-36. https://doi.org/10.2307/1341624.

Ingersoll, Richard M., Philip Sirinides, and Patrick Dougherty. 2018. "Leadership Matters Teachers' Roles in School Decision Making and School Performance." American Educator Spring: 13-17.

http://repository.upenn.edu/cpre workingpap ers/15.\%0Ahttps://eric.ed.gov/?id=EJ117345 2\%0Ahttp://repository.upenn.edu/cpre worki ngpapers/15.

Ingersoll, Richard, and Henry May. 2011. "Recruitment, Retention and the Minority Teacher Shortage." University of Pennsylvania Graduate School of Education Publications 1. https://doi.org/10.1037/e546592012-001.

Ingersoll, Richard, Henry May, and Goerge Collins. 2019. "Recruitment, Employment, Retention and the Minority Teacher Shortage." Education Policy Analysis Archives 27 (37): 1-42. 
Lindsay, Constance A, and Cassandra M D Hart. 2017. "Exposure to Same-Race Teachers and Student Disciplinary Outcomes for Black Students in North Carolina." Educational Evaluation and Policy Analysis 39 (3): 485-510. https://doi.org/10.3102/0162373717693109.

Lopez, Patricia, and Anna Duran. 2021. "The Role of Mentoring on the Retention of Women From Diverse Backgrounds in STEM." In , 271-310. https://doi.org/10.4018/978-1-7998-47458.ch010.

Maryland State Education Association. 2018. "WE NEED TO IMPROVE MINORITY TEACHER TURNOVER." 2018.

https://marylandeducators.org/we-need-toimprove-minority-teacher-turnover/.

National Science Foundation National Center for Science and Engineering Statistics. 2021. "Women, Minorities, and Persons with Disabilities in Science and Engineering: 2021." Alexandria, VA.

https://ncses.nsf.gov/pubs/nsf21321/downlo ads.

Papageorge, Nicholas W, Seth Gershenson, and Kyung Min Kang. 2018. "Teacher Expectations Matter." National Bureau of Economic Research Working Paper Series No. 25255. https://doi.org/10.3386/w25255.

Pearson, L Carolyn, and William Moomaw. 2005. "The Relationship between Teacher Autonomy and Stress, Work Satisfaction, Empowerment, and Professionalism." Educational Research Quarterly 29 (1): 38-54.
Polidore, Ellene, Stacey L. Edmonson, and John R. Slate. 2010. "Teaching Experiences of African American Educators in the Rural South." Qualitative Report 15 (3): 568-99. https://doi.org/10.46743/21603715/2010.1165.

Pope, Devin G, Joseph Price, and Justin Wolfers. 2013. "Awareness Reduces Racial Bias." National Bureau of Economic Research Working Paper Series No. 19765. https://doi.org/10.3386/w19765.

Shwe, Elizabeth. 2020. "Md. School Leaders Find Disproportionate Number of Inexperienced Teachers in Communities of Color." Maryland Matters. 2020.

https://www.marylandmatters.org/2020/07/2 9/md-school-leaders-find-disproportionatenumber-of-inexperienced-teachers-incommunities-of-color/.

Sutcher, L., L. Darling-Hammond, and D. Carver-Thomas. 2016. "A Coming Crisis in Teaching? Teacher Supply, Demand, and Shortages in the U.S." Palo Alto, CA.

Tooten, Tim. 2019. "Maryland Drops to No. 4 in National School Rankings." WBALTV. 2019. https://www.wbaltv.com/article/marylanddrops-to-4-in-national-school-rankingseducation-alert/28941701\#.

Walker, Tim. 2016. "Teacher Autonomy Declined Over Past Decade, New Data Shows." NEA Today. 2016.

https://www.nea.org/advocating-forchange/new-from-nea/teacher-autonomydeclined-over-past-decade-new-data-shows.

Patricia Razafindrambinina is a Chemistry Ph.D. candidate at the University of Maryland, College Park and a science policy advocate with American Geophysical Union's Voices for Science program. Her research focuses on quantifying the effect of particulate matter on climate and the Earth's radiative budget. Her interests include climate change and impacts, environmental justice, sustainability, diversity-equityinclusion, and mental health in STEM. Twitter @PatRazafin

Aditi Dubey is a recent Ph.D. graduate in Entomology from the University of Maryland, College Park, and an Entomological Society of America Science Policy Fellow. Her recent research focused on the environmental impacts of pesticide use in grain production. Her interests include Integrated Pest Management, sustainable agriculture, environmental justice, and promoting diversity and inclusion within STEM. Twitter @Addie_Dubey

Paul B. Ellis is a Master of Public Policy student at the University of Maryland, College Park specializing in Environmental Policy. He is a Green Fellowship recipient at UMD and a summer Graduate Fellow in the office of Montgomery County Council President Tom Hucker focusing on climate and energy policy. His interests include broadening access to academia, government positions, and campaigns by increasing the availability of opportunities like paid internships and improving recruitment and training strategies, political campaigns, identifying plants, and trivia. Twitter @Paul_B_Ellis 
Rachel L Lamb is a Maryland Sea Grant State Science Policy Fellow and recent Ph.D. graduate in Geographical Sciences from the University of Maryland, College Park (UMD). She also earned a Master of Public Policy and Master of Science in Sustainable Development and Conservation Biology from UMD. Rachel's recent research focuses on advancing strategic reforestation in support of climate mitigation and other social and environmental goals. She is interested in identifying climate solutions that simultaneously advance environmental and climate justice. Twitter @Rachel_L_Lamb

Shantam Ravan is a Physics Ph.D. student at the University of Maryland, College Park and is the President of the Graduate Student Policy organization on campus. He is interested in the impacts of policy on climate change mitigation, diversity and inclusion in STEM and bridging the digital divide. Twitter @quantumshantam

\section{Acknowledgements}

Patricia Razafindrambinina is supported by the National Science Foundation Graduate Research Fellowship Program. 